\title{
TWITTER SEBAGAI MEDIA DAKWAH
}

\author{
Ahmad Fathan Hidayatullah \\ Jurusan Teknik Informatika, Fakultas Teknologi Industri, Universitas Islam Indonesia, \\ Kampus Terpadu, Jl.Kaliurang Km.14,5,Sleman, Yogyakarta. \\ Email :fathan@uii.ac.id
}

\begin{abstract}
Social media utilization by moslem community has increased from year to year. In the last decade, Facebook and Twitter are used as means of communication to forward the religious messages and Islamic preaching (dakwah). Among existing social media, twitter is considered having quite high popularity in society. Trend of conducting dakwah by twitter with kultwit apparently has assisted the Muslim preachers to deliver Islamic messages in more interesting way. Furthermore, they gain positive respond from society. Kultwit has become one of the alternative sources to obtain information about Islam and to understand Islam deeper.
\end{abstract}

Keywords: Twitter, kultwit, dakwah, social media.

\section{PENDAHULUAN}

Perkembangan sosial media akhir-akhir ini, telah banyak memberikan berbagai macam kemudahan bagi umat manusia. Berbagai macam informasi begitu mudah diperoleh dan dapat tersebar dengan sangat cepat. Keberadaan berbagai macam fasilitas jejaring sosial telah menggiring masyarakat untuk selalu mengikuti tren dan memperoleh informasi terkini yang terjadi di dunia melalui sosial media.

Sejak berkembangnya era web 2.0, sosial media telah banyak dimanfaatkan untuk berbagai tujuan diantaranya untuk jual beli online, berbagi informasi tempat wisata dan kuliner, berbagi nasihat, memberikan motivasi, serta berbagi informasi tentang segala hal yang berkaitan dengan permasalahan agama. Khusus bagi komunitas muslim, eksistensi sosial media telah membawa mereka kepada gaya baru dalam berinteraksi dengan agama Islam. Komunitas muslim saat ini, telah memanfaatkan media jejaring sosial sebagai media untuk saling berbagi informasi tentang agama Islam. Oleh karena itu, penggunaan sosial media olehkomunitas muslim selalu mengalami peningkatan dari tahun ke tahun.

Peningkatan pengguna sosial media oleh komunitas muslim tersebut disebabkan keberadaannya yang telah banyak memberikan keuntungan bagi mereka. Dengan media jejaring sosial, mereka dapat dengan mudah untuk mendapatkan nasihatnasihat harian dari para dai / ustadz. Mengingat besarnya manfaat yang dapat diperoleh dari keberadaan sosial media tersebut, maka banyak para ustadz yang menggunakannya sebagai salah satu media dakwah kepada kaum muslimin. Strategi dakwah pada zaman Nabi Muhammad shallallahu 'alaihi wa sallam dengan strategi dakwah pada era sosial media sudah sangat berbeda. Dalam kurun sepuluh tahun terakhir, Facebook dan Twitter telah digunakan sebagai sarana komunikasi untuk menyampaikan pesan-pesan keagamaan dan media dakwah.

Oleh sebab itu, saat ini cukup banyak ustadz yang aktif menggunakan berbagai macam media sosial untuk berdakwah. Hal tersebut memberikan kemudahan bagi mereka dapat berinteraksi secara langsung dengan umat muslim. Umat dapat secara langsung 
berkomunikasi dan melakukan tanya jawab tentang persoalah agama yang mereka ingin tanyakan dengan para ustadz dimanapun dan kapanpun mereka berada. Manfaat lain yang dapat diperoleh dari keberadaan media jejaring sosial bagi komunitas muslim adalah sebagai media untuk melawan tersebarnya kesalahpahaman mengenai ajaran Islam kepada non muslim.

Diantara sekian banyak media jejaring sosial yang ada, Twitter memiliki popularitas yang cukup tinggi di kalangan masyarakat. Oleh karena itu, Twitter menjadi salah satu pilihan bagi para ustadz sebagai sarana menyebarkan dakwah.Twitter dapat menjadi alternatif media dakwah dikarenakan keunikan karakteristik pesan yang dimilikinya. Keunikan pesan Twitter yang disebut dengan tweet sangatlah berbeda dengan karakteristik pesan pada media jejaring sosial yang lain. Twitter hanya memperbolehkan para penggunanya untuk menuliskan tweet maksimal 140 karakter. Oleh karena itu, para pengguna Twitter akan membatasi tweet mereka dengan menuliskan pesan yang singkat. Namun demikian, terkadang seseorang perlu menuliskan pesan yang cukup panjang. Untuk mengatasi hal tersebut, maka para pengguna Twitter mensiasatinya dengan membagi tweet mereka ke dalam beberapa bagian menggunakan hashtag tertentu.

Bentuk rangkaian pesan tweet berseri dengan hashtag tertentu dikenal dengan istilah kultwit oleh masyarakat Indonesia.Kultwit merupakan singkatan dari 'kuliah Twitter'.Secara umum, kultwit banyak ditulis oleh para pengguna Twitter apabila membahas topik yang panjang. Topik yang dibahas dapat beragam seperti masalah politik, sosial, olah raga, agama, dan sebagainya.

Berkaitan dengan komunitas muslim, keberadaan kultwit telah banyak dimanfaatkan sebagai sarana untuk menyebarkan dakwah bagi para ustadz. Bagi kaum muslimin secara umum, kultwit menjadi salah satu cara bagi mereka untuk memperoleh pengetahuan serta nasihat Islami melalui pesan tweet yang singkat dan menarik. Oleh karena itu, penelitian ini bertujuan untuk mengetahui respon masyarakat mengenai efektifitas dan manfaat apa yang dapat mereka peroleh dari dakwah melalui kultwit.

Penelitian ini terdiri dari enam bagian. Bagian pertama yaitu pendahuluan yang menjelaskan mengenai latar belakang penelitian ini dilakukan. Bagian kedua membahas tentang penelitian terdahulu yang berkaitan dan mendukung penelitian ini. Pada bagian ketiga, dibahas mengenai landasan teori yang berkaitan dengan penelitian. Bagian keempat menjelaskan mengenai metode yang digunakan dalam penelitian. Bagian kelima berisi tentang hasil dan pembahasan penelitian. Terakhir, bagian keenam membahas mengenai kesimpulan dari keseluruhan isi penelitian.

\section{LANDASAN TEORI \\ 2.1. Dakwah}

Dakwah dapat didefinisikan sebagai suatu tindakan mengajak orang lain untuk beriman dan percaya kepada Allah sebagai satu-satunya Tuhan yang wajib dan berhak untuk disembah. Dakwah merupakan sesuatu yang sangat penting bagi setiap individu baik untuk setiap muslim maupun non muslim. Bagi muslim, dakwah menjadi kewajiban bagi setiap individu. Selain itu, dakwah juga diperlukan untuk mengingatkan setiap muslim untuk tetap berada di jalan yang benar. Bagi non muslim, dakwah adalah sarana untuk mengajak mereka lebih mengenal Islam dan mengatasi kesalahpahaman terhadap Islam.

Esensi dakwah Islam sejak zaman Nabi Muhammad shallallahu 'alaihi wa sallamhingga saat ini ialah dalam rangka mengajak manusia untuk senantiasa berbuat kebaikan dan menjauhi segala perbuatan yang dilarang oleh agama Islam[2]. Dalam konteks yang lebih luas, dakwah memiliki tujuan untuk memperbaiki moral dan perilaku manusia berdasarkan Al Qur'an dan Sunnah. 


\subsection{Twitter}

Twitter merupakan situs micro-blogging yang didirikan oleh Jack Dorsey pada tahun 2006. Saat ini, Twitter menjadi salah satu media jejaring sosial yang cukup populer di dunia. Bahkan, Twitter termasuk dalam salah satu dari lima media sosial yang paling banyak dikunjungi orang.

Berbeda dengan media jejaring sosial yang lainnya, Twitter memiliki beberapa keunikan karakteristik dalam beberapa sisi. Pertama, para pengguna Twitter tidak perlu untuk menunggu persetujuan untuk dapat menerima update dari pengguna lain yang ingin diikuti. Dalam Twitter, dikenal istilah follow dimana seorang user dapat memfollowuser lain tanpa harus mendapatkan konfirmasi dari user yang diikuti. Yang kedua, Twitter mengizinkan penggunanya untuk dapat mem-posting gambar maupun opini dengan pesan singkat yang disebut dengan tweet. Selain itu, Twitter hanya memperbolehkan para penggunanya untuk menuliskan tweet tidak lebih dari 140 karakter.

Twitter juga memiliki beberapa karakter unik dalam pesan singkatnya seperti RT (retweet), hashtag (\#hashtag), dan username (@username). RT merupakan singkatan dari istilah retweet. Retweet merupakan istilah yang digunakan untuk menjelaskan bahwa user melakukan posting ulang terhadap tweet tertentu.Hashtagbiasanya diawali dengan tanda pagar kemudian diikuti suatu kata tertentu tanpa spasi. Keberadaan hashtag menggambarkan topik tertentu yang sedang dibahas dalam sebuah tweet. Gambar 1 merupakan contoh kultwit yang di-posting oleh Ustadz Yusuf Mansur yang membicarakan tentang doa.

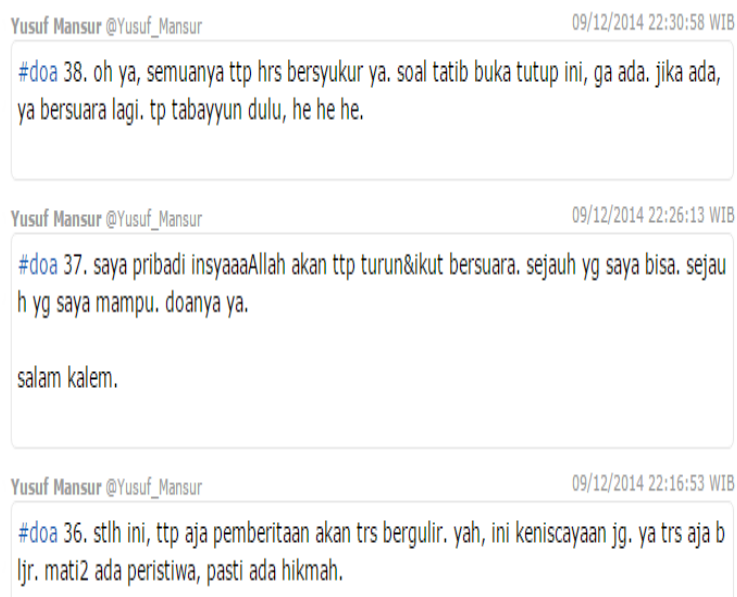

Gambar 1. Kultwit Dengan Hashtag Tertentu.

Simbol lain yang cukup sering ditemui dalam Twitter adalah simbol @username. Username dalam Twitter dilambangkan dengan simbol@yang diikuti dengan nama akun Twitter dari user tertentu. Pada gambar 1 di atas, diketahui bahwa user yang menuliskan tweet menggunakan nama @Yusuf_Mansur. Selain menunjukkan nama pengguna, simbol tersebut juga biasa digunakan untuk berkomunikasi dengan pengguna Twitter yang lain. Seorang user dapat melakukan mention dengan user lainnya dengan menuliskan simbol @username apabila ingin berkomunikasi. Gambar 2 memperlihatkan contoh bagaimana dalam sebuah tweet, pengguna Twitter dengan akun@theAtharee melakukan mention terhadap user dengan akun @abdulahaldafiri.

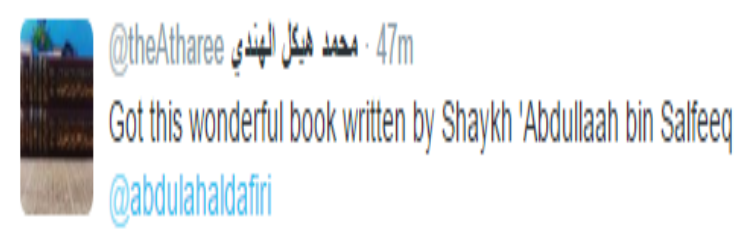

Gambar 2. Mention Akun Twitter.

\section{TINJAUAN PUSTAKA}

Penelitian terdahulu yang membahas hubungan antara teknologi informasi, sosial media, dan dakwah telah banyak dilakukan. 
Agboola melakukan penelitian mengenai pengunaan internet sebagai media komunikasi dakwah Islam. Secara khusus, penelitian ini menganalisis konten dari beberapa website Islam. Berdasarkan hasil penelitian, disimpulkan bahwa komunitas masyarakat Muslim sangat perlu memanfaatkan keberadaan internet untuk menyebarkan informasi tentang Islam. Sebagai contoh, blog adalah salah satu media untuk dakwah di era web 2.0.

Adam, et al telah melakukan penelitian mengenai isu dan tantangan dalam penggunaan blog di Malaysia sebagai media dakwah. Namun demikian, hasil penelitian menunjukkan bahwa pemanfaatan blog untuk berdakwah dan memperoleh informasi tentang Islam oleh kaum muslim muda di Malaysia masih sangat minim.Menurut Lenhart et al, popularitas web blog personal menjadi kurang populer dibandingkan dengan media jejaring sosial di kalangan remaja.

Penelitian yang dilakukan oleh Nassar et al menyatakan bahwa perkembangan teknologi media jejaring sosial baru - baru ini, telah menjadikan sosial media sebagai media yang paling banyak digunakan.Lebih jauh lagi, penelitian ini menambahkan bahwa media jejaring sosial telah digunakan oleh para pelajar di Jordan sebagai media dakwah.

Nurdin dan Rusli mengatakan bahwa fenomena sosial media yang semakin menjadi tren di kalangan remaja, menuntut para dai untuk tidak hanya berdakwah melalui metode ceramah saja, tetapi juga menggunakan sosial media untuk berdakwah. Akan tetapi, mayoritas umat muslim saat ini masih cenderung hanya memanfaatkan sosial media untuk memperoleh informasi tentang Islam dibandingkan dengan menggunakannya untuk dakwah.

\section{METODE PENELITIAN}

\subsection{Pengumpulan Data dan Prosedur Sampling}

Fokus utama penelitian ini adalah untuk mengetahui respon masyarakat terhadap dakwah yang dilakukan melalui Kultwit di
Twitter. Untuk memperoleh informasi dari para responden, penelitian ini menggunakan desain survey penelitian deskriptif. Informasi diperoleh dengan menyebarkan survey kepada 102 responden yang berusia antara 18 - 30 tahun. Kuisioner online disebarkan secara acak mulai dari tanggal 24 November sampai 1 Desember 2015.

\subsection{Instrumen}

Self-administered kuisioner dibuat untuk mendapatkan informasi mengenai respon masyarakat mengenai manfaat kultwit sebagai sarana untuk mendakwahkan Islam. Dalam penelitian ini, kuisioner dibagi menjadi dua bagian. Bagian pertama menanyakan hal yang berkaitan dengan dai atau ustadz yang difollow oleh responden. Di bagian kedua, responden diberikan pertanyaan tentang hal hal yang berhubungan dengan tanggapan mereka terhadap kultwit yang di-posting oleh para dai atau ustadz.

\section{HASIL DAN PEMBAHASAN}

Informasi mengenai respon masyarakat tentang dakwah dengan Twitter telah didapatkan. Dari 102 responden, 81 orang $(79,4 \%)$ diantaranya adalah laki-laki sedangkan sisanya yaitu 21 orang $(20,6 \%)$ perempuan. Selain itu, sebanyak $(95,1 \%)$ responden memiliki akun Twitter dan sisanya (4,9\%) tidak mempunyai akun Twitter.

Berdasarkan $95,1 \%$ responden yang memiliki akun Twitter, mayoritas aktif mengikuti kultwit dari para ustadz dan dai yang mereka follow yaitu sebanyak $68,42 \%$ responden. Sisanya, sebesar $31,58 \%$ dari responden yang mempunyai akun Twitter tidak mem - follow akun Twitter para dai dan ustadz.Dari kuisioner yang diberikan, responden diminta untuk menuliskan maksimal 3 orang ustadz atau dari yang mereka follow di Twitter. Tabel I memperlihatkan 9 daftar nama ustadz dan dai yang di-follow oleh para responden. 
Tabel 1. Daftar Dai / Ustadz yang di Follow Oleh Responden

\begin{tabular}{|c|c|c|c|}
\hline No & $\begin{array}{l}\text { Nama Dai / } \\
\text { Ustadz }\end{array}$ & $\begin{array}{c}\text { Akun } \\
\text { Twitter }\end{array}$ & $\begin{array}{c}\text { Jumlah } \\
\text { Responden } \\
\text { yang Follow }\end{array}$ \\
\hline 1 & Yusuf Mansur & $\begin{array}{l}\text { @Yusuf_M } \\
\text { ansur }\end{array}$ & 29 \\
\hline 2 & Felix Siauw & $\begin{array}{l}@ \text { felixsiau } \\
w\end{array}$ & 26 \\
\hline 3 & Salim A. Fillah & $\begin{array}{l}\text { @ salimafil } \\
\text { lah }\end{array}$ & 16 \\
\hline 4 & $\begin{array}{l}\text { Abdullah } \\
\text { Gymnastiar }\end{array}$ & @aagym & 11 \\
\hline 5 & Fauzil Adhim & @kupinang & 4 \\
\hline 6 & $\begin{array}{l}\text { Muhammad } \\
\text { Abduh } \\
\text { Tuasikal }\end{array}$ & $\begin{array}{l}\text { @ Rumaysh } \\
\text { oCom }\end{array}$ & 4 \\
\hline 7 & Firanda & $\begin{array}{l}\text { @ Firanda } \\
\text { _Andirja }\end{array}$ & 2 \\
\hline 8 & Mufti Menk & $\begin{array}{l}@ \text { muftimen } \\
k\end{array}$ & 2 \\
\hline 9 & $\begin{array}{l}\text { Tariq } \\
\text { Ramadhan }\end{array}$ & $\begin{array}{l}\text { @TariqRa } \\
\text { madan }\end{array}$ & 2 \\
\hline
\end{tabular}

Hasil survey pada tabel 1 memperlihatkan bahwa Ustadz Yusuf Mansur paling banyak di-follow responden yaitu sebanyak 29 orang. Ustadz Felix Siauw dengan akunTwitter @felixsiauw berada di urutan kedua dengan di-follow oleh 26 responden, diikuti oleh akun @salimafillah milik Ustadz Salim A. Fillah dengan 16 responden. Dari 9 data dai / ustadz di atas, responden banyak mem-follow akun berbahasa Indonesia yaitu sebanyak 7 akun Twitter. Hanya terdapat 2 akun dai / ustadz yang berasal dari luar Indonesia yaitu Mufti Menk dan Tariq Ramadan.

Selain menanyakan tentang dai / ustadz yang di-follow oleh responden, penelitian ini juga memberikan pertanyaan tentang seberapa sering para ustadz tersebut mempostingkultwit. Hasil menunjukkan sebanyak $67,1 \%$ responden menyatakan ustadz yang mereka ikuti sering menuliskan kultwit. Sebanyak $14,1 \%$ dari responden memberikan pernyataan bahwa ustadz yang di-follow jarang mem-postingkultwit dan ada 18,8\% tidak pernah mem-posting kultwit melalui akun Twitter mereka.

Pada bagian terakhir kuisioner, responden diberikan tiga buah pertanyaan mengenai tanggapan mereka tentang kultwit yang di-posting oleh para dai/ustadz. Tabel 2 menggambarkan hasil kuisioner di bagian terakhir secara lebih rinci.

Tabel 2. Tanggapan Responden Tentang Kultwit

\begin{tabular}{|c|c|c|c|c|}
\hline \multirow[b]{2}{*}{ No } & \multirow[b]{2}{*}{ Pertanyaan } & \multicolumn{3}{|c|}{ Jawaban } \\
\hline & & Ya & Tidak & $\begin{array}{c}\text { Biasa } \\
\text { Saja }\end{array}$ \\
\hline 1 & $\begin{array}{l}\text { Apakah } \\
\text { menurut anda } \\
\text { kultwit } \\
\text { menarik? }\end{array}$ & $69,8 \%$ & $4,2 \%$ & $26 \%$ \\
\hline 2 & $\begin{array}{l}\text { Apakah } \\
\text { menurut anda } \\
\text { kultwit efektif } \\
\text { untuk dakwah? }\end{array}$ & $72,6 \%$ & $5,3 \%$ & $22,1 \%$ \\
\hline 3 & $\begin{array}{l}\text { Apakah kultwit } \\
\text { membantu } \\
\text { anda untuk } \\
\text { dapat } \\
\text { memahami } \\
\text { tentang Islam? }\end{array}$ & $66,7 \%$ & $5,2 \%$ & $28,1 \%$ \\
\hline
\end{tabular}

Hampir $70 \%$ responden memberikan jawaban bahwa kultwit menarik bagi mereka. Hanya 4,2\% responden menyatakan bahwa kultwit tidak menarik dan sebanyak $26 \%$ mengatakan kultwit biasa saja.Selanjutnya, responden diberi pertanyaan tentang efektifitas kultwit untuk berdakwah. Mayoritas responden (72,6\%) menjawab bahwa kultwit efektif digunakan untuk berdakwah. Sedangkan 22,1\% responden menyatakan biasa saja dan sebanyak 5,3\% menjawab tidak efektif. Yang ketiga, responden diberikan pertanyaan tentang apakah kultwit dapat membantu mereka untuk membantu memahami agama Islam. Dua per tiga responden menyatakan bahwa kultwit membantu mereka dalam memahami Islam. Sebanyak $28,1 \%$ menyatakan biasa saja dan hanya $5,2 \%$ menjawab tidak membantu dalam memberikan pemahaman tentang Islam. 


\section{KESIMPULAN}

Berdasarkan hasil survey dan pembahasan yang telah dipaparkan, maka diperoleh beberapa poin kesimpulan. Pertama, Twitter masih banyak digunakan oleh para responden. Hal tersebut merupakan indikator bahwa Twitter masih menjadi salah satu dari media jejaring sosial yang cukup populer di kalangan remaja. Kedua, Twitter sudah digunakan oleh para dai / ustadz di Indonesia sebagai sarana untuk menyampaikan dakwahnya kepada khalayak.Tren berdakwah melalui Twitter dengan kultwit telah membantu para dai / ustadz untuk menyampaikan pesan - pesan keislaman dengan lebih menarik bagi masyarakat. Selanjutnya, dakwah para dai / ustadz melalui kultwit telah mendapatkan respon positif dari mayoritas responden.Selain itu, kultwit menjadi salah satu sumber alternatif bagi masyarakat untuk mendapatkan informasi mengenai agama Islam serta dapat membantu dalam memahami Islam secara lebih mendalam.

\section{DAFTAR PUSTAKA}

A. Go, R. Bhayani dan L. Huang, "Twitter sentiment classification using distant supervision," CS224N Project Report, Stanford, 2009.

A. K. Agboola, "Religious Communication and Internet Usage: How Do Muslims Fare on the Web?," Middle-East Journal of Scientific Research 20 (Language for Communication and Learning), pp. 11-20, 2014.

A. Lenhart, K. Purcell, A. Smith dan K. Zickuhr, "Social media and young adults," dalam Pew Internet \& American Life Project, 2010.

B. Bensaid, "On Islamic Da"wah and Sustainable Development," World Journal of Islamic History and Civilization, vol. 3, no. 2, pp. 48-56, 2013.
F. Adam, M. M. Anuar dan A. H. Ali, "The use of blog as a medium of Islamic da'wah in Malaysia," International Journal of Sustainable Human Development, vol. 2, no. 2, pp. 74-80, 2014.

I. A. Nassar, D. J. A. Hayajneh dan D. M. K. Almsafir, "Relation between social network and Da'wah to Islam: A case study on Jordanian students," International Journal on Islamic Applications in Computer Science and Technology, vol. 1, no. 1, pp. 9-18, 2013.

L. Shahnaz dan S. Wok, "Religious motives for using facebook among university Muslim students," dalam Seminar Kebangsaan Media dan Dakwah (SMED) 2011, 2011.

M. Amin, "Information Technology (IT) dan urgensinya sebagai media dakwah era kontemporer," Jurnal Dakwah Tabligh, vol. 14, no. 2, Desember 2013.

N. Nurdin dan R. Rusli, "Social media adoption and use within Indonesian Muslim scholars: A possibility of adoption and use for da'wah purposes," dalam 12th Annual Conference on Islamic Studies (ACIS) Proceedings, Surabaya, 2012.

N. V. Kosheleva, "Muslim da'wah and its influence on Islamic Studies of the USA," American International Journal of Research in Humanities, Arts and Social Sciences, vol. 4, no. 1, pp. 102106, 2013.

S. Ras, "Twitter \& Da'wah: A Look Into How Social Media Can Effectively Spread The Message of Islam". 